\title{
ARTIGOS
}

\section{A Vontade Santa}

\author{
Maria Sylvia de Carvalho Franco
}

Credo in unum Deus, Patrem omnipotentem, factorem coeli et terrae. Subjacente à religiosidade explícita em "A Hora e Vez de Augusto Matraga", o sentido encadeado com firmeza ao longo de sua trama é a abjuração dessa fé. $\mathrm{O}$ que se desentranha do variado relato de situações é, simplesmente, a criação do homem, encontrando-se o próprio homem no centro desse mistério.

A escolha da religiosidade como caminho dessa descoberta não é arbitrária. Também nesse conto, o fulcro é o Sertão, ao mesmo tempo campo ideal que resume a totalidade das condições possíveis para a existência humana e a concretização particular, determinada, lugar e momentos reais dessa existência. Nesses dois sentidos e exprimindo sua síntese, o "Sertão é o Mundo" (1). Nesse quadro, o autor deslinda a gênese da consciência, da liberdade, da moralidade, aqui, nesta morada de párias, onde a impossibilidade objetiva de vencer as privações persiste juntamente com uma ideologia de promessas: num futuro fugidio, mas sempre ao alcance da súplica, fica o momento da redenção em que os últimos serão os

(1) Antônio Candido, "O Homem dos Avessos", in Tese e Antítese, S. Paulo Comp. Ed. Nacional, 1964. primeiros. Como sabedoria de oprimidos, toma forma uma religiosidade impregnada de sofrimento e salvação.

Daí, no conto de Guimarães Rosa, a religiosidade ser caminho aberto para a existência e também modo de conhecimento. Os progressos de Matraga realizam-se como graça e como revelação: após os acontecimentos que destruiram seu antigo estilo de vida, perde contato com o exterior e fecha-se na busca de sua razão de ser. Nesse estado, sua vida reiniciou-se e seu caráter firmou-se através de passos em tudo identificáveis com as práticas ascéticas e místicas: a aspiração ao absoluto, o esforço de purificação, a união com Deus, e o movimento contrário de retorno ao mundo e de reorientação da conduta. Dado isto, a reviravolta sofrida por sua alma encerra um enorme contrasenso: o contato com a divindade é impossível e o íntimo acordo final dá-se profanamente consigo mesmo e com seus iguais.

Esta escolha de Guimarães Rosa fornece a chave para se adiantar sua visão do homem e sua ética. Enquanto se move nas mil capas cristalizadas do cotidiano exterior, e é por ele determinado, o ser humano simplesmente não existe. Por isto, o nascimento da pessoa e sua perfeição têm por requisito a renúncia ao mundano. 
Se assim é, já se anuncia a cerrada unidade que sustenta "A hora e vez de Augusto Matraga". Nos vários níveis em que se pode desdobrar o conto das condições sócio-econômicas que lhe serviram de matéria, passando pelo filtro da experiência vivida pelos personagens, até a doutrina sobre o homem e o cosmos - se depara com a coerência dos critérios subjacentes à sua elaboração. No plano mais evidente da narrativa percebemos existências inteiramente pobres, onde se inscrevem a violência e o misticismo. Pelos caminhos da religiosidade compreendidos nesse mundo rústico, Guimarães Rosa prossegue para o triunfo "inventado" de Matraga. Ficasse ele preso aos "dados" e a religiosidade sertaneja não passaria de compensação pela impotência terrena inescapável, aferrada às esperanças escatológicas e ao salvador divino: escreveria, então, uma crônica de derrota. Não obstante, esse mundo carente e opressivo, horizonte dos :eventos, funda o esforço heróico de domínio da vontade mediante privações materiais, tema do conto, que suporta, por sua vez, a tese da liberdade moral. Neste passo, realidade concreta, expressão literária, poșição filosófica, fundem-se na mesma verdade.

Espero, nos parágrafos acima, ter atinado com as proposições fundamentais da narrativa. Para demonstrá-las, Guimarães Rosa faz a aventura do herói seguir o evangelho de Cristo em seus grandes tempos: Advento, Paixão, Ressurreição.

"Matraga não é Matraga, Matraga não é nada". Do caos se inicia a criação do homem - nhô Augusto. No princípio, sua figura tem contornos dados pelo que houve antes e fora de si mesma. Nesse tempo, em sua longa espera, Matraga é família e é propriedade. "É Esteves. Augusto Esteves, filho do Coronel Afonsão Esteves, das Pindaíbas e do Saco da Embira". Apenas desse modo existe Matraga, por obra e graça de sua colocação no mundo e por este fato se distingue dos outros seres que também o habitam. Mas nada, essencialmente, diferencia cada indivíduo nhô Augusto inclusive - e o universo originário do arraial da Virgem Nossa Senhora das Dores do Córrego do Muricí. "Ele é duro, doido e sem detença, como um bicho grande do mato". E lá, a brutalidade é natural e uniforme: num final de festa leiloa-se gente e um leilão é façanha coletiva. Assim, por trás da anedota escandalosa da mulher apregoada, se desenham os destinos vulgares: em todos eles, numa continuidade inerte, interior e exterior se confundem e somente refrões ecoam desses homens. "Bota a Sariema no leilão!. . . Bota no leilão!. . . Bota no leilão!..." Uma só voz destoa e questiona, não do objeto da venda, e sim apenas de sua circunstância: "Respeito, gente, que o leilão é de santo". Repelida, ela encontra no temor divino a coragem de seu argumento: "Coisa de Igreja tem castigo, não é brinquedo". Atoa, pois assim baixo não vale a fé, que encontra sua eficácia em tom mais forte: "Sino e santo não é pagode, povo!" e nhô Augusto abafou a arrelia.

$E$ unicamente por essa questão de mais e de menos que nhô Augusto e os outros estão apartados. No fundo, são os mesmos. O povo abusa das mulheres, e nhô Augusto está no meio dele, só que podendo mais, "alteado, peito largo, pisando pé dos outros e com os braços em tenso, angulando os cotovelos". Alguém diz "cinco mil reis", nhô Augusto berra "cinquenta mil réis", e arremata a Sariema.

Esta posse maior sustenta o clarão de sua "voz de meio dia" e a opulência de seus pescoções, contra a fala baixa e o gesto parco, só de três dedos, com que o capiau amoroso da mulher-atoa procura levá-la. Esta posse maior 
também dá a ele a aclamação do povaréu - "nhô Augusto leva a Sariema, viva nhô Augusto", e o apoio de seus guarda-costas, contra a solidão do capiauzinho, estapeado pelos cacundeiros e "empurrado para o denso do povo, que também queria estapear". Esta posse maior lhe garante ainda a verdade descarada com que despacha a Sariema "- Você tem perna de Manuel Fonseca, uma fina e outra seca (...) Vá-se embora frango d'água, some daqui", contra a mentira embaraçada da mulher acusada de preferir o capiau: "Foi, mas agora eu gosto de você... o outro eu mal e mal conheci". Cena maior, a provocada por nhô Augusto, mas ainda assim repetição das outras agitações que haviam estalado em todos os quadrantes da massa, que a hora era de briga. De briga geral, instintivo, nhô Augusto também, buscando "assombros de homens para entrar no meio ou desapartar".

Por sobre todas as coisas que constituiam nhô Augusto e o distanciavam dos demais, reverte a sua prepotência. Num retorno auto-destrutivo, o exercício sem regra de sua vontade arrasa tudo o que lhe servia de lastro: família e propriedade.

Da riqueza desdeixada, nada sobrou: "as terras no desmando, as fazendas escritas por pagas, e tudo de fazer ânsia por diante, sem portas, com paredes brancas".

$\mathrm{Na}$ família, largou-se devastador. A filha, sempre ignorada; a mulher, fruida só nas carnes; a parentela, afrontada. Põe e dispõe, joga-os daqui para lá, como se não fossem gente. Daí os seus contratempos: Dionora é dona de si. Ela, que já contrariara os pais para casar-se com nhô Augusto, desafia-o depois para acompanhar um novo escolhido. Nessa decisão, não é presa de um impulso, mas reflete e delibera. Reconhece o presente insuportável, compara-o com a renovação que se an!:mcia, prevê as possíveis consequências. A troca do desprezo pelo amor, o medo imenso aplacado, a coragem da morte, tecem sua opção.

No contexto mais geral do conto, a fuga da mulher exprime o extermínio da família que, ao lado da ruina da propriedade, significam a liquidação das marcas exteriores que dão corpọ a nhô Augusto. Imerso na violência contra as próprias fontes que o nutriam, dá cabo de si. Não obstante, o episódio de Dionora não se esgota nessa função. Fosse assim, e bastaria mencionar o acontecimento, tal como, adiante, é sumariamente registrada a prostituição da filha, sinal da irrecuperável perda do antigo estado de coisas. Dessa jovem, nada se sabe; no entanto, entra-se na intimidade de Dionora, de seus juízos, lágrimas e esperanças.

Esta mulher já traz à cena o conceito de humanidade em Guimarães Rosa. Não é casual a escolha de um ser espoliado para introduzir esta noção, pois a indigência é uma constante nas pessoas verdadeiras presentes na narrativa. A condição de penúria é central em sua teoria sobre a determinação social do homem, de seu poder de libertação e de constituição do próprio mundo. Tanto maior será a escravidão do espírito, quanto mais enrredado estiver em suas manifestações objetivas. "Vende teus bens, dá aos pobres e terás um tesouro nos céus". E a partir do despojamento de Dionora que se desenham a sua figura $\mathrm{e}$ as qualidades contrárias que a marcam: fraca-forte, submissa-voluntariosa; desamparada-independente. Erguendo-se sobre tais atributos, imediatamente referidos à ambiguidade normal da existência, ela é a mais real das personagens e a mais conforme ao módulo da condição humana. Orientando-se dentro da situação vivida, ela faz o que é possível e ocupa assim o centro da escala ao longo da qual o autor constroi as suas expressões de humanidade. Nos 
dois extremos, as esplêndidas esquematizações dos heróis e suas façanhas, em dois sentidos opostos: em Matraga a purgação da renúncia é correlata à posse máxima de si; em Quim, a miséria efetiva perde-se em uma atividade sem propósito e corresponde à anulação total de sua vontade.

Tudo assolado, chega o princípio das dores. Pobre, solitário, traído, pouco resta de nhô Augusto. Dessa destruição inicial de sua natureza pregressa começam a surgir sua personalidade e seus atributos fabulosos. Esta metamorfose do personagem, de homem imperfeito a santo, dá-se ao mesmo tempo que, no fluxo dos eventos, o autor faz a passagem da realidade para um mundo ideal. O episódio que sintetiza esta mudança é o da desforra vã tentada por nhô Augusto. Conforme o código do sertão, a única maneira de restabelecer sua integridade perdida seria a destruição do adversário. No encalço disto ele sai, como sairia todo outro criado no apreço máximo da coragem e no hábito arraigado da violência. Até aí, age ele reativamente, "sem ponderados pensamentos", obedecendo a preceitos e valores imemoriais, perdidos na rotina de sua existência, No entanto, o que tem em mira é totalmente inexequível: todo outro "teria percebido a chegada do azar, da unhaca, e passaria umas rodadas sem jogar, fazendo umas férias na vida". Mas nhô Augusto "era ainda couro por curtir": escapa ao senso comum, a finalidade de sua ação afasta-se da utilidade, a impossibilidade absoluta é enfrentada, o esforço torna-se sobre-humano, o suportável atinge o inverossímil. A vingança tragicamente buscada o entrega a seus inimigos, completando-se, com a imolação de seu corpo, o extermínio dos predicados garantidos por sua posição social. "Não tem mais nenhum nhô Augusto Esteves das Pindaíbas?"
No plano mais superficial da narrativa, esta pergunta indica o desígnio consciente de supressão física do adversário, mas sua forma deixa inequívoco o significado mais profundo que encerra: liquida-se nhô Augusto-família e nhô Augusto-propriedade. Este é um dos dois sentidos de sua chacina. Aparece surrado e marcado a ferro por sua antiga gente e pelo rasteiro capiauzinho, assinalando, esta degradação, o fim de seu estado anterior. Mas esta mesma redução à miséria elimina nele, o peso dos condicionamentos exteriores, e o regenera. Assim liberado, de sua paixão de sangue, pó e fogo, começa a ressurgir Matraga, imortal.

Ilhado em um mundo ideal permanece contudo o personagem cercado de realidade. Esta é, primeiramente, o suporte das figuras e eventos entrelaçados na aventura do herói. O mísero casal de negros, os samaritanos que socorreram nhô Augusto, agem como pessoais reais: sua liberdade não é infinita, mas condicionada à situação em que se encontram. Pesam as probabilidades de sucesso: "Os outros não vão vir para campear defunto porque a pirambeira não tem descida (...) E como tem um bezerro morto, na biboca, lá de cima vão pensar que os urubús vieram por causa do que estão pensando". A escolha da viagem para exprimir a inquieta e difícil busca de solução, por nhô Augusto, tem suas raízes na instabilidade efetivamente sofrida pelo sertanejo brasileiro, para quem a mobilidade sempre se apresentou como o recurso único contra as adversidades. Finalmente, Joãozinho Bem-Bem, o chefe jagunço em quem nhô Augusto irá se medir, realiza, em grau máximo, os predicados legítimos do homem do sertão. Nele, virtude, coragem, violência, estão inextrincavelmente ligados.

Em segundo lugar, a realidade existente é a referência necessária para a constituição da própria região do absoluto. De um lado, ela compõe os limi- 
tes de ida e volta de Matraga. Sua largada só é possível porque preencheu os requisitos de pessoa humana: a extrema pobreza, compatível com a liberdade moral, nos termos atrás referidos. Matraga se identifica com o que de mais ínfimo existe à sua volta: é cuidado pelo casal de negros, agasalhado em seu casebre. A partir daí, suas ações visam a perfeição e transcorrem sempre como negação expressa e radical das condições sociais de existência. Em vez de urgência pela reconquista da família, há tranquila renúncia: "Uma tristeza mansa, com muita saudade da mulher e da filha, e com um dó imenso de si mesmo". Em vez da contenção adulta, a perda da censura convencional: "e chorou muito, um choro solto, sem vergonha nenhuma, de menino ao abandono. Em vez do orgulho, dolorosamente vencido, a humildade: "se eu pudesse ao menos ser absolvido de meus pecados!..." De seu sofrido encontro com a humildade, traço diametralmente oposto à antiga prepotência, resulta afinal a sobrevivência da alma, que coincide com a cura do corpo. Nesse ponto, inteiramente desprendido, nhô Augusto já não é deste mundo: "féria feita, a vida já se acabara, e só esperava era a salvação de sua alma e a misericórdia de Deus Nosso Senhor". Aplacado, mantem-se num estado ideal, apresentado sempre como negação da sociedade em geral e também do seu eu anterior: seu trabalho intenso e improdutivo, tem o maior desapêgo das coisas materiais, afasta-se do convívio, foge ao prazer.

Nessas condições "inventadas" cresceu e persistiu a paz: ele "não tinha tentações, nada desejava". Entretanto, a negação do mundo por nhô Augusto não podia ter foros de eternidade. Sua luta pelo domínio do espírito deu-se ao longo de seu esforço pelo uso do corpo: quando começou a avançar na beatitude, estava também apto a andar. Em- bora se mantenha escondido, nhô Augusto tem presença sensível, existe para outros que, saídos da corrente da realidade de novo para lá o arrastam. "Tião da Thereza ficou bobo de ver nhô Augusto". Nesse contato, tem início o seu retorno. No conceito daquele homem que veio de fora, a imortalidade penosamente buscada significa apenas que deixou de ser gente, para pior: marido, pai, dono, inimigo, patrão, tudo deixara de ser. "Não tem mais nenhum nhô Augusto Esteves das Pindaibas".

O desprezo recebido não o largou mais. Diante do sentimento que feria fundo sua pessoa, começa a ruir sua indiferença. Percebe o mundo à sua volta que, aleatório, interfere na região ideal: tudo "era consequência de um estouro de boiada na vastidão do planalto por motivo de uma picada de vespa na orelha de um marraz bravio, combinado com a presença, nesse mundo, do Tião da Thereza". Sua almejada união com a divindade é penosa e irrealizada e mesmo seus exercícios ascéticos guardam algo dos antigos métodos terrenos: "Pro Céu eu vou, nem que seja a porrete". No tempo certo, a comunicação com seu semelhante é imediata e dela não se refaz.

Começa a volta, mas não como reaproximação do "mundo", definitivamente perdido e renegado, mas como retorno a si. São os caminhos da subjetividade que o atraem para a vida. Sente a nostalgia de suas qualidades pessoais e retoma o gosto pela coragem, a honra, a lealdade, que assumem importância de salvação: "assim tão mole, tão sem homência, será que posso entrar mesmo no Céu?" O prazer se insinua: "se bebesse e cigarreasse, se ficasse sem trabalhar nem rezar, haveria de recuperar sua força de homem e seu acerto de outro tempo". Retoma o gôsto pela violência: lembra, saboreando, a "briga com a família inteira, pai, irmão, tio da moça que eu tirei de casa, semana antes 
de se casar". A afetividade desperta, com a filha e Quim voltando-lhe à memória. Pouco a pouco as sensações crescem dentro dele, enquanto o mundo adquire uma qualidade sensorial: água, luz, calor, são os seus elementos. Os sentidos fazem-se mais e mais alertas: colhe aguda impressão do corpo, tem fome e sono fartos, vê ouve e cheira com delícia. Numa alegre e esparramada sensualidade dá-se sua reconciliação com a natureza e consigo mesmo: sem culpa, "tirou tragadas, soltou muitas fumaças e sentiu o corpo se desmanchar, dando na fraqueza, mas com uma tremura gostosa, que vinha até o mais de dentro, parecendo que a gente ia virar uma chuvinha fina".

O mesmo caminho o aproxima de seus semelhantes. A caracterização de qualidades sensíveis carrega a apresentação do bando de jagunços. São "bem montados, bem apessoados, bem armados". E o chefe: "forte, alto, os dentes brancos limados em acume, olhar dominador, sorriso bonito e mansinho de moça". Entre nhô Augusto e Joãozinho Bem-Bem a atração é instintiva e a simpatia se estabelece profunda e imediata. Disposições afetivas análogas os unem: trocam préstimos, a admiração recíproca sela sua amizade. "Nossos anjos da guarda combinaram e isto para mim é o sinal que serve". Nessa relação, o sentimento de humanidade cresce. Sacia os olhos no banquete que oferece aos jagunços. Aprecia as virtudes próprias de seus novos amigos, mas estes provocam também o seu corpo. Nhô Augusto namora e apalpa. A força dos braços, a agilidade das pernas, as cicatrizes das mãos, a posição dos homens em briga, o excitam. Contudo, não se deixa tentar pelas inclinações do coração para seguí-los, mas reafirma a viva sedução: "nunca hei de me esquecer dessa sua bizarria, meu amigo, meu parente, Seu Joãozinho Bem-Bem".
Ao léu, no vai e vem ao encontro da natureza e do homem, distende-se, afinal, feliz: "Oh! que coisa boa a gente andar solto, sem obrigação nenhuma e bem com Deus!... No fim de suas andanças, em meio ao grande bem estar, a satisfação maior: encontra Joãozinho Bem-Bem. De corpo e alma prestes a serem reconquistados, revê o amigo e em sua íntima união e valorosa oposição a ele, conhece seu momento de liberdade.

Esse encontro dá-se logo depois da morte, por traição, de Juruminho, jagunço que agradara sobremaneira a nhô Augusto. Seu chefe apronta-se para cumprir a regra do sertão e vingá-lo. Nhô Augusto, que já sofrera tão intensamente o império da vingança, opõe-se à judiação anunciada para a família do culpado, coisa "que nem Deus não manda, nem o diabo não faz". O herói fica insensível à memória de Juruminho, desconhece o forte impulso que o liga a Joãozinho Bem-Bem e cumpre o seu dever benfazejo, protegendo a desconhecidos cuja sorte em nada lhe interessava. Enfrentam-se os dois amigos, homens presos por uma poderosa simpatia e que se respeitam como valentes e leais. O caráter íntimo e pessoal de suas relações torna sua guerra mortal. Não há outra maneira de salvaguardar o conceito alto e extremo que fazem um do outro: a crise violenta de suas relações é condição para que permaneçam intactas. Assim também, a intensidade e o gôzo do corpo a corpo entre ambos estão na proporção dos laços fortes que os unia. Feridos de morte, mas empatados, a solidariedade mútua se restabelece, intocada. "- Espera aí, minha gente, ajudem a meu parente alí, que vai morrer primeiro..." "- Morro, mas morro na faca do homem mais maneiro de junta e de mais coragem que eu já conheci”. Experimentando a satisfação do justo, na oposição a outro homem justo, nhô Augusto encontra o 
seu verdadeiro Eu e recupera sua identidade: "Perguntem quem é aí que algum dia já ouviu falar no nome de nhô Augusto Esteves, das Pindaíbas". Então, Augusto Matraga fechou um pouco os olhos, com um sorriso intenso nos lábios lambuzados de sangue e de seu rosto subia um sério contentamento".

\section{Pobreza, Violência e Opressão}

Do primeiro ao último momento da história, a violência está presente e os personagens, alternadamente, a exercem e a sofrem. Poderoso, nhô Augusto a esbanja por todo lado; destruído, a suporta com igual fartura; refeito, unifica o seu dar e receber. Não são apenas os poderosos que a empregam, mas qualquer um. Basta lembrar que a queda de nhô Augusto vem com a sanha do pobre capiau, o namorado da mulher-atôa, a surrá-lo. Ao fim do leilão, as brigas impetuosas e generalizadas irrompem sem motivo aparente, e em sequência a brincadeiras. Finalmente ela aparece como única medida entre nhô Augusto e Joãozinho Bem-Bem. A violência encharca o conto: afrontosa na prepotência dos coronéis, alienada no tráfico dos capangas, reativa no povo, absoluta entre amigos-inimigos.

Nessa insistência, Guimarães Rosa enfeixa o ethos da cultura brasileira. De onde vem essa violência e porque se dissolve nas representações do "doce" povo brasileiro? Onde o equívoco: na brutalidade, ultimamente realçada na criação artística, ou no estereótipo de brandura? Essas perguntas dissociativas despistam; a indagação deve antes focalizar como esses têrmos contraditórios são conciliados nas existências brasileiras.

Começo por uma noção vulgarmente associada aos males brasileiros: o latifúndio. Modelando as condições natu- rais aqui encontradas, a prática do colonizador português constituiu-o como a unidade básica da sociedade. A sua custa nutriu-se um punhado de proprietários, em seu benefício trabalhou um batalhão de escravos, à sua sombra viveram homens livres e pobres, quase uma ralé.

Essas categorias - produção mercantil, propriedade privada, escravidão, "ralé" — são essenciais ao sistema colonial. A primeira delas conferiu sentido às demais: foi a finalidade da ação eccnômica que converteu as terras em grandes propriedades e forçou os homens que as trabalharam ao regime servil. Entretanto, por maior que fossem as ambições do colonizador e por mais que se traduzissem em quantidades a produzir, maior era a terra que thes servia de base. Interminável ela também sustentou aqueles que não foram nem senhores, nem escravos: apenas gente sem qualificação precisa. Nada possuiram, a lugar nenhum pertenceram a ninguém estiveram presos. Dispersos pelo sertão, errando em bandos, agrupados em ranchos, empregados em aventuras, iam para onde a pobreza das roças os conduzisse, por onde o gado os tangesse, perseguindo os favores $\mathrm{e}$ os perigos do serviço pessoal onde os encontrassem. Trouxeram no corpo magro os sinais dessa vida de restrições e suportaram, nas almas secas, um perene sentimento de carência. Vencer esse despojamento crônico, foi o que tentaram através do único bem que lhes sobejava: a própria terra, que atravessaram incessantemente em busca de uma redenção nunca encontrada.

Esta instabilidade é sintoma da marginalização que sofreram e da qual resultou uma organização social, sem linhas nítidas de integração: sistemas de parentesco, de circulação de bens econômicos, de governo e mesmo um sistema religioso específico, não podem ser identificados claramente no interior 
desses grupos. Nem se distinguem, tampouco, princípios firmes de regulamentação social. Os interesses econômicos que dominaram os setores organizados para a produção mercantil não tiveram razão de ser naquela pobreza completa. Entretanto, estiveram suficientemente perto desses grupos pobres impedindo que a tradição se firmasse como esteio da ordem social. Nessas vidas em que os atributos humanos quase não chegam a realizar-se numa cultura exterior a noção de pessoa lastreia a concepção que o homem faz de si mesmo orienta a conduta em relação a seu próximo e limita suas reações ao mundo social. Esta noção funda uma moralidade que sanciona a honra, a coragem e a violência, mas a conduta organizada por esses valores estaca no limiar do social, onde se abre um claro de inconsciência e passividade. Das dimensões pessoais da existência, conhecimento e ação projetam-se para o sobrenatural onde a adversidade e a impotência se abrandam.

O mesmo estado de coisas que modelou o homem desvalido e violento, no limite inferior da escala social, forjou, no extremo contrário, o homem poderoso e também bruto: o grande proprietário. Vinculado à terra, teve seu mundo confinado ao pequeno reino que organizou em vista de seus interesses. Do ponto de vista econômico as barreiras de suas propriedades foram aparentes, pois integravam-se numa imensa rede de circulação de mercadorias. Em têrmos de relações sociais imediatas as vastidões que comandou traduziram-se pelo isolamento. Assim, também nos grupos dominantes, as relações pessoais foram o vínculo básico, fundando uma dominação diretamente autoritária e praticamente ilimitada.

Desse quadro, surgem pobres e ricos reduzidos ao cumprimento de um destino comum: o da solidão. Do lado do pobre, marcado pela instabilidade, isto o aproximou do vazio social: nesse povo sem vizinhança, sem parentela, sem política, sem liturgia, quase sem trabalho e sem recreio, o único elemento a apresentar continuidade é o próprio sujeito. Do lado do rico, as amarras da terra determinaram família, economia, política, religião, mas fizeram também que ficassem reduzidas a interesses de pequenos grupos. Num caso como no outro, a pessoa definiu-se como a unidade última da organização social.

Aí está delineada uma sociedade carregada de tensão, mas tediosamente homogênea: personalidades que se repetem, ou pequenos grupos que se justapõem. Esta forma é coerente com a antiga "igualdade" social, observada pelo menos na região centro-sul do país, cujas raízes estão na generalizada pobreza em que viveram suas populações. Pobreza já originariamente permeada de ambição e seguida de enriquecimento rápido, base das diferenças sociais. Este processo impediu os grupos que se alçaram a uma posição dominante de ficarem nitidamente delimitados e definirem dentro deles uma cultura exclusiva. A efetiva indiferenciação inicial, a formação de camadas superiores apenas endinheiradas, a inacabada expropriação do homem pobre e sua exclusão do processo produtivo, articularam-se a um tipo de dominação também todo ele firmado na pessoa e posto em prática através da contra-prestação de serviços e benefícios. Contudo, entre proprietários e dependentes não se estabeleceram laços obrigatórios e suas associações foram estritamente convencionais. Salvo no plano político, onde elas ganhavam alguma estabilidade, as obrigações de auxílio e proteção contraídas pelos grupos dominantes podiam ser impunemente transgredidas. $E$ isto frequentemente aconteceu: premido por seus interesses o grande proprietário violava o trato estabelecido com seu pessoal, interrompia a cadeia de contra-prestações e expunha ele próprio a contingên- 
cia de sua dominação. Isto é o que permite a um zé ninguém, "ir guardando a raiva miúda na massa-mãe do ódio e tirar sua desforra". Mas esta desforra continua sempre como a do capiau namorado da mulher-atôa: contra a prepotência de um opositor determinado, perdendo-se numa dimensão puramente subjetiva.

As considerações acima indicam que a violência generalizada, e seu freio nos limites privados da existência, estão estruturalmente dados na sociedade brasileira. Os conflitos entre homens pobres, a luta entre proprietários, a arbitrariedade destes em relação a seus dominados, a revolta destes últimos, são momentos de ruptura que refletem reajustamentos constantes da organização social e econômica, provocadas pelas contradições que estão na gênese da sociedade brasileira e que até hoje fazem sentir os seus efeitos.

Feitas essas considerações, a violência espalhada pelas páginas de Matraga aparece referida aos próprios fundamentos da sociedade brasileira. A construção dos personagens e de suas ações, no conto de Guimarães Rosa, correspondem à situação real, que sanciona e ao mesmo tempo refreia a violência. Ele a apresenta inteiramente dentro dos limites mantidos pela organização social: malbaratada em rebeliões sem finalidade maior que pendências pessoais. $\mathrm{O}$ desperdício de energias e a perda de valores humanos que assim se determinam não chegam a constituir problema na estória contada. A violência que existe no pobre, mas fica tolhida, chega a ser sugerida uma vez, no canto do capiau atormentando nhô Augusto: "Sou como a ema, que tem penas e não voa".

A opressão é vigorosamente denunciada nessa obra, mas o é de maneira muito geral, como infortúnio que a todos - do mais miserável ao mais poderoso - igualmente pode atingir. Se é exato representar a violência difusa por todos os setores da sociedade, é decisivo que ela seja experimentada de maneira particularmente diversa por dominantes e dominados. Isto não aparece como um assunto claramente tratado. É certo que essa diferença de sofrimentos vem explícita na sorte de Quim Recadeiro e de nhô Augusto: um perde-se irremediavelmente e o outro salva-se. É certo também que nhô Augusto é despojado, para em seguida passar pela degradação. Contudo, nos destinos reservados a esses personagens, nota-se que a validade dos motivos de Quim não é questionada. Tanto quanto nhô Augusto, Quim é pintado como herói, e não como um pobre diabo que perdeu a visão de si mesmo. E esta é a grande distância que separa os dois.

O primeiro vai ao encalço das agruras e tudo suporta impulsionado pela obsessão do Eu: é o imperativo de salvar sua honra, seus interesses, seu prestígio, que lhe dá a coragem do impossível; depois, é a busca de sua liberdade que o tira do transe aflitivo. É o amor-próprio que o afunda e o retira da desgraça e todo seu caminho é realizado em direção a si mesmo.

Ao contrário, em Quim, o sentido dos passos funestos vem da adesão ao Outro. Tal como em nhô Augusto, toda normalidade desaparece de sua conduta. Todavia, quando sua escolha deixa de estar subordinada à adequação dos meios ou à previsão das consequências, para derivar de um comando absolutamente sem condições, este revela um sujeito que por inteiro não se pertence. $\mathrm{O}$ rapaz conhece sua incapacidade para a luta: “... sou medroso. Eu cá não presto". Não obstante, sua lealdade ao patrão extingue nele a consciência de objetivos próprios, promove a identificação com o superior e o conduz ao ataque suicida. Mais ainda, resumindo o caráter quase animal de suas reações em favor de seu dono, Quim morre sem 
a piedade ou o rancor dos adversários: apenas é abatido.

Assim vistos, o comportamento e a destruição de Quim correspondem à alienação que de fato pesa sobre os homens pobres e dependentes, submetidos à dominação pessoal. Há, nessa passagem do conto, uma adequação perfeita entre realidade social e sua representação literária. Entretanto, o autor faz os objetivos de Quim parecerem sobre-humanos; seus motivos, nobres; seu ato, belo. Desse prisma, as avaliações do autor caracterizam-se claramente como ideologia: suas interpretações são as mesmas desenvolvidas na vida coletiva de que participa.

Para continuar este argumento, recorro a conclusões que já apresentei em outro trabalho sobre a igualdade ilusória entre superiores e inferiores, que na verdade funda uma opressiva técnica de dominação, posta em prática mediante a contraprestação de lealdade, favores, obrigações de compromissos firmes do lado do pobre, tênues do lado do rico.

Esse quadro de referência faz inteligível a conduta de Quim e permite localizar as implicações ideológicas na representação de Guimarães Rosa. Na medida em que a figura de Quim deixa de parecer lastimável, o Autor se faz intérprete de uma visão conservadora da sociedade brasileira. Manter todos os Quins fiéis e leais, em troca de retribuições menores, arbitrariamente concedidas ou negadas, é algo profundamente arraigado na ordem estabelecida. Constitui uma técnica utilizada com êxito mesmo em regiões "modernizadas". Associada às pressões que acompanham aos salários, ela redefiniu-se e reforçou o processo de dominação. Paga-se ao camarada e soma-se, às dívidas que contrai no armazém e na farmácia, as velhas obrigações morais.

A diferença na força dos compromissos do rico e do pobre, aparece retratada no ronto. Quim percebe ser alheio à desgraça de nhô Augusto e conhece mesmo as regras a seguir, por ocasião da fuga de Dionora: "Eu podia ter arresistido, mas era negócio de honra, com sangue só pro dono, e pensei que o senhor podia não gostar". A despeito disso, sacrifica-se pelo patrão. E nhô Augusto? No mal-estar sentido ao saber como morrera Quim, é sempre ele próprio a referência de seus pensamentos: "E o Quim, o Quim recadeiro um rapazinho miúdo, tão no desamparo - morrendo como homem, por causa do patrão, um patrão de borra, que estava pr'ali no escondido, encostado, que nem como tivesse virado mulher!..." Aceita naturalmente a abnegação de Quim; apenas se recrimina por não estar à altura de feito tão alto e por não retribuí-lo de modo adequado. Esta pa'sa fazia parte, formalmente, da associação estabelecida entre eles; de fato, porém, podia faltar a ela impunemente. Haja visto que a vingança de Quim fica em suspenso e este pecado não impediu nhô Augusto de alcançar a perfeição que buscava. Isto porque, na verdade. Quim não contava.

Algo totalmente diverso ocorre entre Joãozinho Bem-Bem e seus homens. Neste caso, a garantia da sujeição aparece firmada por uma trama de interesses: para o chefe jagunço, era vita! manter seu séquito. Assim, observa à risca a parte que lhe toca nos compromissos. Juruminho clama vingança e Joãozinho Bem-Bem, desapiedado, atalha a súplica das vítimas: "É a regra, senão até quem é mais que havia de querer obedecer a um homem que não vinga gente sua, morta de traição?... É a regra".

Nenhuma diferença deveria pautar as relações nhô Augusto e Joãozinho Bem-Bem com seus sumordinados. Num mundo feito de pessoas, valorizar a humanidade de todos seria um dever para todos. Mas há esquecimento de nhô Augusto pelo insignificante Quim, e 
respeito do jagunço por Juruminho. Censura ligeira perturba o primeiro: sente remorsos, e o "mundo" o condena, na pessoa de Tião da Thereza, mas reparar o mal feito não é um imperativo. Enquanto isto, a implicável vingança do chefe jagunço o enaltece e lhe dá dimensão para enfrentar, como igual, o engrandecido nhô Augusto. Dois pesos e duas medidas: faltar a Quim não constitui obstáculo no caminho radioso de nhô Augusto; faltar a Juruminho destruiria a Joãozinho Bem-Bem. Apenas a desimportância de Quim e a indispensabilidade de Juruminho fundam essa distinção: aí está uma moralidade que se diferencia conforme variam os interesses. E vemos que, enquanto costume, ela anima os personagens.

Contra os argumentos acima se deverá dizer que o caminho de nhô Augusto era justamente para fora e em oposição àqueles costumes. Não vingar, fosse lá quem fosse, era a máxima observada por ele, negando as regras do mundo que repudiara. $\mathrm{O}$ perdão domina toda sua última fase, como vitória sobre a aflita tentação de desforra. Mas a seu lado cresce Joãozinho Bem-Bem, que personifica exatamente os valores "normais" daquela sociedade. Lá está ele, igualmente herói: vingativo e justo. Indo adiante, vê-se que os dois protagonistas são equivalentes. $\mathrm{O}$ respeito $\mathrm{e}$ a lealdade sedimentam suas relações, sobretudo no momento em que são violentamente rompidas. De seu confronto não resultam vencedor e vencido, e morrem na mais completa admiração e solidariedade recíprocas. A luta mortal entre ambos não significa uma representação a mais da antinomia do Bem e do Mal, mas implica na valorização de duas ordens distintas de finalidades: santidade e violência são igualmente aprovadas.

Voltando a nhô Augusto: também ele transita por esses dois mundos de valores. Sua primeira fase é de afirma- ção da violência; a segunda, de negação; na terceira ela reaparece, transfigurada. Esta sequência exprime as transformações de sua consciência e de sua prática: primeiro, é um autômato num mundo mecânico, depois um santo em busca do absoluto, e por último se humaniza num mundo real. A tensão entre o primeiro e o segundo desses termos (as tentações que sofre e vence exprimem isto) promove o terceiro, que sintetiza os anteriores: ao alcançar a categoria de pessoa, ele exerce a sabedoria da segunda fase, no gesto da primeira. Vejamos como esse esquema é explorado no conto.

Em toda sua última fase, nhô Augusto resiste e cede aos modos de ser qu abandonava, mas trazia em si, malgrado tudo. As inclinações "naturais" que penosamente combate, correspondem, na verdade, aos valores, atitudes e comportamentos legítimos no meio em que viveu, e aos quais aderia de modo automático. Assim, a relação entre nhô Augusto e Joãozinho Bem-Bem é uma complicada teia de íntima afinidade e inconciliável oposição. De modo contraditório, o Jagunço, expressão máxima da violência que Matraga repudia, é também aquele a quem mais ama, admira e respeita.

A despeito disto, leva adiante sua torturada luta entre exterior e interior: comovido pela beleza crua do cangaço, não cede à sua sedução. As privações suportadas viram de ponta-cabeça seu lugar no mundo: existiu como miserável e se fez outro. Não obstante, este novo ser guardou muito do antigo: a violência inicial não se perde, mas muda de sentido ao fundir-se à mansidão conquistada. Num mundo essencialmente violento, só há um modo de resistir: violência igual. $\mathrm{E}$ este recurso extremo, nhô Augusto usa para opor-se à execução da regra que considera absolutamente perversa: “... coisa que nem Deus não quer, nem o diabo não faz". 
O retorno ao tema da violência como imperativa propõe a questão da unidade do mundo rústico. A ficção, o cinema, o ensaio, têm oposto cangaço e latifúndio, glorificando um e condenando o outro. Esta representação distorce a situação real: ambos foram constituídos unitariamente e o cangaço está, muitas vezes, a serviço do latifúndio sofrendo repressão política como derivação de lutas pelo poder que não lhe concernem diretamente. No conto isto é evidente: prepotência, arbitrariedade, opressão, alienação, fazem-se igualmente presentes num e noutro. Nessa medida a representação literária é fiel à situação concreta que lhe serve de matéria, exprimindo a determinação social do indivíduo nas situações particulares em que vive. Entretanto ao lado dessa apreensão adequada do real, se destaca um conteúdo utópico, aos socii pré-determinados, se contrapõe um homem livre. É certo que a liberdade de Matraga tem limites: sua eficácia estava condicionada a valer-se da violência usual no meio em que vivia. No entanto, o sentido de sua prática foi definido contra seus novos atributos e contra os mores estabelecidos: o homem manso de coração, fiel às suas intenções, age violentamente contra o amigo, encarnação do costume.

Ao trazer à cena o princípio da autonomia, se completa o sentido utópico que pode ter o conto: ele questiona os valores e práticas de todo o mundo rústico reconstruído.

Esta autonomia concerne, entretanto, à pessoa de nhô Augusto e nela se esgota; não tem nenhum sentido social. A luta por ele travada em favor das vítimas não visa um opositor que socialmente se determinasse pela opressão de seus dominados, numa relação necessária à continuidade do sistema como um todo. Jagunços e roceiros não são termos antitéticos ao modo de senhores e escravos ou patrões e empregados. No caso considerado, a prepotência é imprescin- dível para que subsista o grupo de cangaceiros, enquanto o desvalimento em que se encontra a família visada é determinada pelo sistema social como um todo. É preciso ir além dos limites do conto para se indicar que o abuso do cangaceiro sobre a população é essencial à ordem estabelecida: a ação de Joãozinho Bem-Bem revela esse sentido quando se evidencia que o cangaço é determinado por, e sustenta, aquela mesma ordem. Agir no sentido de sua preservação é igualmente preservar o sistema em geral. Se levarmos isto em conta, as representações românticas sobre o cangaço como solo fértil à liberdade, cede passo à representação mais real de que é constituído por homens que apenas nos limites de sua existência pessoal reagem contra as adversidades sociais que os marginalizaram. Como formação social eles não investem contra o sistema de poder, mas são postos a seu serviço. Se assim é, a liberdade perseguida e conquistada por Matraga fica despida de sua aparência utópica, a representação literária readquire fidelidade às condições reais e revela seu caráter ideológico, na medida em que exprime uma avaliação positiva dos feitos daquele personagem, dentro dos limites em que foram contidos. Matraga é herói, e sua liberdade se inscseve no plano moral e não político.

As representações do autor, vistas até aqui, são congruentes com a realidade, compondo uma ideologia conservadora. O modo como são construídas as relações entre nhô Augusto e Quim deixa isto indiscutível. Nelas não há, num sentido estrito, deformação da realidade. $\mathrm{O}$ autor apenas as apresenta tal qual são. Mas nessa "objetividade" se esconde o grande escamoteamento que se pode atribuir a ele. Quim totalmente alienado é o próprio modelo do sertanejo miserável; sua figura dá a medida exata dos Quins verdadeiros. Acentuar abstratamente suas qualidades, sua lealdade e 
sua coragem, desconhecendo o contexto de dominação onde se inscrevem e ganham sentido, é que introduz o colorido conservador.

Mas também é preciso reconhecer que a representação da ordem vigente, pelo autor, não é de todo passiva. O rigor e riqueza de sua observação se encarregam disto, fazendo com que aprenda também os elementos que são contrários às coisas estabelecidas. Estes germes fundam, em suas interpretações, as linhas tendentes a transcender a realidade e a voltar-se contra ela. As pessoas miseráveis e livres resumem, essas tendências. Que o pobre desvalido chegue a impor-se é uma imagem de todo incompatível com uma sociedade autoritária e opressivamente controlada pela dominação pessoal. Esse desvio de seu pensamento em relação à ordem existente faz dele portador da utopia central de nossa época: a transformação da sociedade do ponto de vista das camadas inferiores na escala social. Não será preciso lembrar que esta concepção prende-se a correntes que, mesmo no sertão, embora de maneira descontínua, têm se tornado ativas, convertendo-se em luta por um novo estado de coisas. O significado prático de sua obra se completa quando deixa patente a violência permeando toda a sociedade brasileira, embora a mantenha confinada às dimensões pessoais da existência.

Aí está, pois, como a visão de Guimarães Rosa, que é muito adequada à ordem existente na sociedade brasileira, acompanha também de perto, em suas avaliações, as tendências em aberto nessa sociedade. Por causa desta estreita vinculação, pode-se dizer que o caráter utópico, que é mais imediatamente visível e o mais sedutor em seu conto, aparece como subproduto de sua ideologia. Sua visão, quase ajustada à ordem de fato, é competente para apontar a opressão e a violência difusas por toda parte, embora não chegue a diferenciá-las: a tirania imposta a Quim parece-lhe semelhante à iniquidade sofrida por nhô Augusto, a violência deste é comparável à do Jagunço. Assim se recupera a coerência dos pontos de vista implícitos no conto. Nesse quadro, ideologia e utopia aparecem não apenas como termos opostos, mas correlativos.

\section{Religiosidade e Salvação}

"Toda necessidade de salvação é expressão de uma indigência e por isto a opressão econômica ou social é uma fonte eficiente de seu nascimento embora de modo nenhum seja a exclusiva". ( ${ }^{2}$ )

A que tipo de indigência estará respondendo a experiência religiosa em Matraga? Sua ânsia de salvação virá de seu rebaixamento até aos "pobres de espírito"? Sua eufórica identificação com o mundo representará a vida no milênio? Em suma a religiosidade de nhô Augusto transpõe para o plano literário a religiosidade dos grupos pobres da sociedade brasileira?

As ciências sociais informam o quanto a magia está mesclada à religião dos povos camponeses. Os grupos rurais brasileiros não deixam de se enquadrar nessa observação pelo menos quanto à sua cultura original. Entre eles, as técnicas agrícolas que repousam no pressuposto da simpatia mesclam-se à observância das fases da lua, com seu caráter animista, somam-se à observância dos dias desastrosos, em que o trabalho é proibido para propiciar aos "deuses" locais, e combinam-se ainda com o calendário religioso que coincide com a divisão de ano segundo o ritmo agrário. Vê-se, por aí, como a religião dos

(2) Max Weber, Economia y Sociedad, vol. II, p. 165. 
grupos pobres da área rural brasileira tem um caráter obviamente prático.

Ao lado dessas atividades, difusas por todas as populações rurais, ocorrem os movimentos messiânicos, fenômenos coletivos de intensificação do ânimo religioso, acompanhados de modificações no estilo de vida. Esses movimentos cabem na explicação geral de que a necessidade de redenção, por parte dos grupos pobres e oprimidos, traz consigo uma religiosidade ligada à aparição de um salvador. Além desse significado, o movimento de Antonio Conselheiro e seu Império do Belo Monte, que servirá de exemplo neste trabalho, permite uma interpretação que põe em relevo o nexo de sua emergência e de seus característicos com a organização da sociedade brasileira.

Para que esse movimento fique inteligível, é preciso ter presente a estrutura dos grupos rurais, sua fluidez e diferenciação pouco precisa, a grande mobilidade que comportam. Neles não se observam, também, linhas de organização que poderiam compartamentalizar as relações sociais: inexistem fortes laços de sangue, fixação a determinado local, ligação específica a um grupo, hierarquia social rígida, tabús ou outros tipos de impedimentos formalmente estabelecidos, capazes de tolher o estabelecimento de vínculos "comunitários" que constituam o suporte para uma religiosidade congregacional. $\mathrm{O}$ caráter nada tradicional ou fechado dos grupos rurais brasileiros, se revela plenamente quando vemos o quanto eles permitem a formação desses "ajuntamentos" espontâneos.

De modo bem coerente com esse quadro, vemos Antonio Conselheiro iniciar sua carreira de vagabundo itinerante, seguido por fiéis da mais variada procedência e qualificação social: entre eles, os criadores ricos "se irmanavam a sitiantes e simples vaqueiros, a escra- vos fugidos". (3) (Pereira de Queiroz, Messianismo, p. 208).

Imediatamente ao lado deste setor rural está outro, que na verdade o determina, e que inclui os agrupamentos urbanos. Isto significa a presença paralela de uma sociedade mais estratificada, com sistema político, administrativo e atividades mercantís. Como se estivesse a suprir a carência crônica desses elementos de organização social e econômica, no meio rural, o grupo de Antonio Conselheiro cessa suas andanças e se estabelece. O arraial do Belo Monte cresce como centro de produção e comércio artesanal e agrícola. Define-se uma hiesarquia interna ao grupo: Antonio Conselheiro no vértice, seguido de seu conselho (guerra, economia, vida civil, vida religiosa) e de sua guarda. Determina-se também uma estratificação baseada na riqueza e no prestígio. Desenvolvem-se controles sociais, com raízes religiosas, mas com a função de fortalecer a vida familiar e política.

Estas indicações mostram o quanto esse movimento messiânico correspondia praticamente às necessidades da existência. "O destino terrestre era levado muito a sério pelo Conselheiro, que instituíra uma série de normas para regulamentá-lo, a fim de que realmente em Canudos se realizasse o Paraíso Terrestre". Pode-se afirmar, que, em Canudos, as práticas religiosas de negação do mundo, conscientemente observadas pelos fiéis como meio de salvação, na verdade tiveram a função de introduzir, em suas existências, uma incipiente "racionalização" das atividades. O "comunismo" de Canudos deixa isso inequívoco: consistiu numa técnica para regularizar o provimento de meios de vida. Assim, os que habitavam o povoado, fosse qual fosse a tarefa em que se

(3) Maria Isaura Pereira de Queiróz, O Messionismo no Brasil e no Mundo. São Paulo, Dominus, 1965. 
empenhassem - artesãos, comerciantes, agricultores - deviam entregar ao Conselheiro um têrço do produto de seu trabalho para o sustento comum. Espelha-se, nesse despojamento, uma contribuição ativa para resolver os problemas de suprimento, o que introduz, na conduta religiosa, um elemento de cálculo, tendo em vista objetivos práticos. A religiosidade de Canudos inclui também a intenção de preservar o Paraíso Terrestre conseguido e de defendê-lo das ameaças exteriores. As virtudes ordenadas pelo Messias e praticadas pelos fiéis assumem um caráter coletivo, correspondendo à necessidade de exaltação de todos e encobrindo a necessidade material de redenção. Nessa linha se compreende a agressividade de Canudos, a guerra com a sociedade mais ampla que lhe era adversa e da qual seus membros procuraram escapar.

Este quadro mostra o quanto a negação e a fuga do mundo, características de nhô Augusto, estão longe da religiosidade dos grupos rurais que, em quaisquer de suas formas, seja acomodando-se às condições sociais, seja opondo-se a elas organizadamente, assume um caráter prático.

Em primeiro lugar nada aproxima nhô Augusto, com seu trabalho improdutivo, do roceiro que se vale do sobrenatural justamente com fins produtivos. Em segundo, em sua experiência não está em jogo nenhuma "imortalidade coletiva", mas apenas a sua própria. Deixa intocada a ordem social que rejeita. Nada o aproxima dos participantes de Canudos, onde a salvação pessoal se apresenta sob a forma de modificações do mundo social circundante, em favor do povo desgraçado. Em nhô Augusto, apenas a orientação de sua própria vida condiciona a melhoria que busca: as promessas que tem em mira são de ordem puramente espiritual e sua indiferença ante o mundo vão e sem sentido se traduz na rigorosa disciplina ético-religiosa a que se submete. Uma orgulhosa solidão é a grande inimiga que combate e que vem a ser, ao mesmo tempo, o próprio fundamento de sua salvação. Parece-me que esta é a chave para se compreender sua religiosidade. A humildade estava longe de ser compatível com o senso de dignidade do homem que fôra. Dobrar-se ante um Padre é a última coisa que faz Augusto Esteves das Pindaíbas e do Saco da Embira; recuperar sua auto-estima é a primeira coisa que acontece a Matraga.

Eliminado um possível parentesco entre o anseio de salvação de nhô Augusto com o de párias e, pelo contrário, exposta a resistência de seu orgulho, volta-se à pergunta inicial: a que indigência corresponde a experiência religiosa em Matraga. Isto nos leva a indagar sobre as relações entre Deus, o mundo e o homem, tal como representadas nesse personagem.

Os ideais do cristianismo são os mais evidentes. Lá está, constantemente, a presença de um Deus omnipotente e perfeito frente à insuficiência de suas criaturas. Dentro desses ideais enquadra-se a tentativa para libertar-se da imperfeição pessoal, da inclinação origìnal ao pecado, que a religião entende como inevitável. No sentido desse alvo se orienta a vida de nhô Augusto. Assim, de acordo com o cristianismo, cujo mais importante dogma corta a possibilidade de identificar-se à divindade como fim da ação religiosa, seu obietivo é conformar-se às qualidade agradáveis a Deus. $\mathrm{O}$ método seguido aproxima-o do asceta negador do mundo. Procura alcançar um cotidiano santo e, com este fito, provoca um rebaixamento das funções do corpo, se mortifica, e orienta sua atenção e sua vontade para o que é exclusivamente religioso. Vê-se, em seus dias, o esforço físico intenso, o isolamento, a inibição sexual, a meditação, a repetição das jaculatórias que previnem o espírito das ciladas exteriores. 
Assim, a conduta que deverá levá-lo às qualidades que aspira é lutadora, na ânsia de vencer o corpo e o espírito na busca de uma virtude concebida como antagônica ao "mundo". Desse modo, sua prática religiosa traz necessariamente, junto com o domínio dos impulsos naturais e com a sistematização da vida, uma crítica às situações sociais correntes. Dí, a separação violenta de sua existência pregressa: quebram-se os laços com a família e com a propriedade, com os interesses políticos e econômicos. Dentro dos limites acima caracterizados, esta sua fase é ativa: o asceta que nega o mundo traz intimamente $\mathrm{o}$ requisito da luta contra $\mathrm{o}$ mundo.

Mas não significa isto, em nhô Augusto, uma oposição à ordem social, mas unicamente, de maneira abstrata, uma rejeição do "mundo", com suas irracionalidades, gozos e alegrias. Observa o mandamento do amor ao próximo, mas ele próprio é a referência última desses atos. Bem de acordo com a ética cristã, suas boas ações, realizadas como penitência, têm o sentido de reabilitação dos pecados cometidos anteriormente. Nessa conta-corrente de ações boas e más, para que o peso recaia mais sobre o primeiro prato da balança, a bondade para com toda criatura passa a ser o seu lema. Mas na verdade, as intenções que animam seus bons atos visam transformações a serem operadas em sua própria pessoa. Afastou-se radicalmente das coisas mundanas, mas o seu objetivo é sempre a vida interior: é enorme sua luta contra o egoísmo e a brutalidade que traz dentro de si, mas segue inerte diante dessas maldades quando exteriores a ele. (Mesmo a oposição a Joãozinho Bem-Bem tem por referência antes sua própria salvação que a defesa da família oprimida. A função desta, no conto, é completar o quadro necessário para caracterizar a ação justa do herói). Todo o esforço de aperfeiçoamento se desen- volve dentro da ordem social e à revelia dela. Neste ponto fica bem evidente o "aristocratismo" de nhô Augusto: ao comum dos mortais, com suas virtudes e pecados menores, se deixa o que é acessível a eles, neste ou no outro mundo. A aproximação ao divino dá-se justamente pelas vitórias obtidas contra as tentações de salvação e de vida fáceis. Nhô Augusto as sofreu e venceu, mas a despeito dos anos de exercício não logrou fazer da santidade uma rotina de vida.

O objetivo longínquo e atormentado, mas o único válido como meta do próprio é, para ele, atingir a perfeição. Este é o significado das regras negadoras do "mundo", que se impôs. Por força da vontade aperfeiçoou-se, diferenciando-se do comum dos mortais, mas justamente por esse caminho expôs-se ao maior dos pecados: a identificação com Deus. Seu esforço de sentidade reverte, em última consequência, na grande heresia: o Homem-Deus não é consubstancial com o Pai, mas foi divinizado pelo seu heroismo e pelos seus atos. Contra isto se eleva, pelos séculos afora, o símbolo de Nicéia: Credo in unum Deum. Contra este dogma, em última instância, se desenvolve toda a última parte do conto, onde, afinal, Matraga livra-se de seus tormentos.

Nessa última parte, suas práticas desviam-se completamente do passado moralmente ativo, orientando-se para a contemplação e a mística, para a posse do divino neste mundo. Para representar o novo caminho, Guimarães Rosa vale-se da antiquíssima idéia de renascimento, espalhada em todas as partes, por todos os tempos. As divindades mitológicas que personificam as forças da natureza, o herói guerreiro que obtém forças mágicas, o feiticeiro tribal que adquire seu carisma, o jovem índio que alcança status de adulto, Jesus Cristo, todos renascem, no sentido de que passam a ter um novo caráter depois 
de um sacrifício ou de um ritual. A representação do estado de ânimo de nhô Augusto em completa intimidade com a natureza lembra, mais de perto, a exploração dos mitos da primavera e de seus deuses. Também ele, como essas divindades, baixou aos infernos e teve paralisadas suas potencialidades para, no tempo certo, voltar das profundezas da terra e sobre ela abrir-se em toda sua riqueza.

As descrições de Guimarães Rosa contrastam fortemente, agora, com as da fase ascética. Os elementos que seleciona e põe em relevo, em Matraga voltado para o mundo, estão saturados da presença material, de seu próprio corpo e dos outros seres, da natureza inteira, fundindo-se tudo isto numa euforia do espírito que se estende até o sentimento de Deus. Desviando-se cada vez mais do Criador, nhô Augusto chega a sentir o sopro do panteismo. A impressão que esta parte comunica é a de uma orgia e tem mesmo, em algumas passagens, força erótica. Um erotismo que não se dirige a um objeto determinado, mas apanha unitariamente a tudo e a todos, como uma forma de conhecimento. Estreitamente ligado a isto, projeta-se uma outra sabedoria, que lhe traz, afinal, a almejada descoberta do sentido do mundo, sem nenhuma mediação entre este e seu espírito, entre este último e Deus.

Assim, pois, essa fase de nhô Augusto não aparece como negação do mundo sensível, mas de comunhão com ele. Há uma constante e firme presença do humano na exaltação de nhô Augusto. Ao mesmo tempo que progride na sensação de paz com Deus e o mundo, amplia-se também o domínio e o uso integral de seu corpo, num caminho inverso ao percorrido na fase anterior. Sua contemplação vagabunda e errante, comparada à rígida disciplina que abandonou, apareceria como um gozo reprovável. Mas é que, agora, não está mais cingido a nenhuma regra de ação: não tem mais em mira o cumprimento da vontade divina, mas diretamente a fidelidade a si mesmo. De outro lado, sua existência é de completa fuga do mundo: vive do nada e não faz nada. Reduz sua atividade ao mínimo e alheia-se do mundo social circundante. Em manifesta indiferença pela ordem social dada, não faz juízo nenhum sobre os Jagunços, apenas experimenta frente a eles, admiração, emoção, amor. Frui um estado interno de plenitude, de onde deriva, afinal, a reorientação prática de sua vida, permanecendo sua pessoa o centro de todo o resto. $O$ ponto culminante de seu esforço vem expresso na morte, portanto no absoluto desprezo das coisas terrenas. Neste ponto reaparece o orgulhoso abandono do mundo, reafirmado por nhô Augusto também ao seguir os caminhos da contemplação.

Já se vê, agora, a que tipo de indigência responde $o$ anseio de salvação em Matraga. Não é nenhuma penúria material que inspira as questões éticas e religiosas tratadas no conto, mas as necessidades do espírito. Nhô Augusto anda atrás da própria integridade, procurando escapar à indigência interior, desvendada pela indigência material a que ficara reduzido.

Violência e religiosidade são dois componentes básicos dos grupos rurais brasileiros. No decorrer do conto, a violência gerada pela ordem social e contida dentro dos limites pessoais vem representada com maior adequação à realidade que a religião. Esta, no meio rural, tem predominantemente um sentido prático, seja associado à magia, seja ligado os movimentos de organização das relações sociais, da atividade econômica e mesmo política, segundo o modelo "civilizado". Estes aspectos nada tem a ver com o solitário nhô Augusto. Resta considerar a vida religiosa como puro e simples recurso compensatório 
para os infortúnios terrenos, a salvação como contrapartida de impotência. Entretanto, mesmo essa forma de alheiamento do mundo com esperanças de redenção postas fora dele, pouco se relaciona com a orientação de nhô Augusto. Conforme procurei mostrar, todo o seu período ascético, embora tenha pressuposto a fé num Deus Salvador, na verdade corresponde à necessidade de compreensão do sentido da vida, na busca de uma unidade consigo mesmo, com os outros homens, com o mundo. Não é uma atitude de renúncia, mas de conquista.

Esta fase ascética é de extrema penúria material associada à liberdade e ao domínio de si. Tal contexto parece indicar que a ambientação do conto - o sertão carente e despojado onde o homem fica nú e só — é, além de imagem das condições reais de existência, expressão de um campo ideal, onde desaparece o valor de todas as inclinações, dos talentos do espírito, das qualidades do temperamento, dos bens da fortuna e da cultura, para refulgir, "de seu próprio brilho, a simples vontade". O sertão, nesse sentido, está fora do mundo, e constitui o campo da vida ética.

Os homens são estritamente determinados, enquanto presos a seus desejos $\mathrm{e}$ interesses da vida corrente (em toda a primeira parte do conto). Pelo contrário, a conduta de nhô Augusto, desde o minuto em que fica socialmente reduzido a nada, firma-se numa autonomia crescente. Sua luta constante é contra os entraves subjetivos e contra os limites exteriores. Nesse embate, suas ações perdem por completo o sentido de utilidade, renuncia totalmente à felicidade "natural", pratica um bem que não lhe traz nenhuma compensação agradável, enfim, desprende-se de tudo que possa desviar seus atos da finalidade nobre de sua vida: alcançar a virtude. Esta, pouco tem a ver com a "conquista do céu", não é usada como meio, é almejada como fim em si mesma, respondendo a uma exigência intelectual. Esse objetivo difícil de ser logrado se revela, no fim de contas, insatisfatório. A vontade de nhô Augusto esbarra sempre com os obstáculos vindos de sua natureza sensível e em suas ações retas experimenta o peso dessa coerção. Quando a pressão aumenta, e as tentações apertam, entramos no limiar da fase "mística" de nhô Augusto. Aí então ele se reconhece, num idílio, como parte do mundo sensível. Em toda a identificação de nhô Augusto com a natureza e os homens, vemos espalhar-se uma libido sem peias. A fase repressiva da ascese cede passo a um estado isento de inibições, de plenitude das virtualidades humanas.

Ao lado da acentuação que faz dos sentidos, Guimarães Rosa privilegia, na ação de seu personagem, a atividade da consciência: Matraga não é fragmento da natureza, submetido às suas leis, mas alguém que conduz sua vida orientado pela idéia de liberdade. $\mathrm{Na}$ fase ascética se nutre de uma rigorosa solidão que exclui mundo e Deus como princípios de moralidades. A um ele nega, para identificar-se com o outro. Visa a perfeição, atributo divino e deixa velada a diferença essencial entre a criatura e o Criador. Na fase seguinte, em vez de elevar o homem a Deus, é a este que identifica com os homens e o mundo. Em ambos os casos, a "religiosidade" de Matraga exprime a abjuração da fé cristã. É uma ética extra-divina que o encaminha para um justo acordo entre felicidade e virtude.

O lugar e o sentido da religiosidade no meio rural brasileiro são inteiramente deslocados no conto. Esse elemento da situação social serve apenas como ponto de partida para desenvolver-se uma problemática independente do sertanejo. A 
religiosidade deste visa o mundo objetivo, não apenas práticas de adaptação à natureza, mas também no ajustamento humano. O Santo, aí, é milagreiro. A esta figura se opõe a Santidade de Matraga, subordinada ao conhecimento de si e ao auto-domínio.

Ao caracterizar a dominação, a violência e a pobreza, o Autor permanece mais próximo das condições reais, matéria de que tece a trama dos acontecimentos.

Enquanto está preso aos "fatos", sua posição é vacilante, e ora aparece como portador de uma ideologia conservadora, ora exprime as tendências de transformações implícitas na realidade. Sua apurada observação da vida sertaneja responde por isto: ele a conhece adequadamente, captando as ambiguidades e contradições nela contidas. Entretanto, não ultrapassa o nível em que se apresentam nas personalidades e na trama das suas relações, sem ir aos seus fundamentos e sem criticá-los. Por isto, os desenvolvimentos do conto tornam-se inconsistentes em termos das próprias concepções que o sustentam. Assim, por exemplo, as relações entre Quim e nhô Augusto há certamente uma representação "objetiva" da realidade tal qual é. Mas esta neutralidade faz com que os desenvolvimentos em torno da noção de lealdade encerrem um desvio ideológico incompatível até mesmo com a tese central do conto: Quim, sem nenhum domínio de si, é tão herói quanto Matraga, consciente da liberdade. De outro lado, por vezes a observação da realidade e sua representação literária, associadas às teses teóricas tornam-se reciprocamente adequadas. Assim, o privilégio concedido ao pobre e oprimido, na história, pode simbolizar o despojamento que é requisito da liberdade moral e, coerentemente, acumular o sentido de negação de ordem estabelecida. Entretanto, ao nível em que se estruturam os mais importantes elementos do tema da liberdade, o autor afasta-se das condições reais e as usa apenas como ponto de partida e forma de expressão. Não é a religiosidade do sertanejo que está impressa na atitude e nas ações de Matraga, mas os dilemas do intelectual "civilizado".

Resta apenas indicar o que é óbvio: o conto se alimenta das grandes correntes do pensamento moderno, do qual Guimarães Rosa participa. Nele, a vida ética, colorida por tintas idealistas, é sopesada em termos da determinação social do homem e do inconsciente. Sente-se mesmo ao longe, na escolha do sertanejo pobre como expressão de humanidade, a utopia central de nossa énoca: a transformaç̃̃o da sociedade "de baixo para cima". 